

\section{PENGERTIAN IMD dan ASI EKSKLUSIF}

> Inisiasi Menyusui Dini ( IMD) adalah perilaku pencarian punting payudara ibu sesaat setelah lahir. Hal ini sangat dibutuhkan, karena bayi setelah lahir langsung mendapat asupan gizi dari ASI. Pemberian ASI secara dini juga sangat bermanfaat bagi ibu,terutama untuk merangsangkelancaran ASI. Program IMD merupakan program pendukung dari pemberian ASI Eksklusif pada bayi

> ASI eksklusif adalah ASI yang diberikan pada bayi selama 6 bulan pertama kehidupannya tanpa tambahan cairan lain seperti susu formula, jeruk, madu, air teh, air putih dan tanpa tambahanmakanan padat seperti pisang, pepaya, bubur susu,biskuit dan nasi tim. Setelah6 bulan baru mulai diberikan makanan pendamping ASI (MPASI). ASI dapat diberikan sampai anak berusia 2 tahun atau lebih. 


\section{Manfaat IMD dan Asi Eksklusif}

> Pentingnya pemberian IMD merupakan salah satu cara dalam menyukseskan Kesehatan bayi secara fisik dan psikis yang selama ini masih kurang diterapkan karena cenderung mengabaikan IMD dengan anggapan bahwa putting mengandung kuman dan kotor pada saat ibu bersalin (Fauziah Nasution, 2017).

> Manfaat Asi Untuk Bayi

1. ASI sebagai nutrisi

2. ASI meningkatkan daya tahan tubuh bayi

3. ASI eksklusif meningkatkan kecerdasan

4. ASI eksklusif meningkatkan jalinan kasih sayang

5. Menyebabkan pertumbuhan yang baik 


\section{Manfaat IMD dan Asi Eksklusif}

> Manfaat Asi Untuk Ibu Hamil

1. Mengurangi perdarahan setelah melahirkan

2. Mengurangi terjadinya anemia

3. Menjarangkan kehamilan

4. Mengecilkan rahim

5. Lebih cepat langsing kembali

> Manfaat ASI untuk Keluarga

ASI tidak perlu dibeli sehingga ekonomis dan praktis karena dapat diberikan dimana saja dan kapan saja.

$>$ Manfaat ASI untuk Negara

Pemberian ASI dapat menurunkan angka kesakitan dan kematian anak, mengurangi subsidi untuk rumah sakit, mengurangi devisa untuk membeli susu formula dan meningkatkan kualitas generasi penerus bangsa 


\section{DETERMINAN PELAKSANAAN IMD}

Faktor determinan yang berkontribusi terhadap pelaksanaan IMD meliputi pendidikan, pengetahuan, sikap ibu, tindakan bidan, dan dukungan keluarga. Secara teori, lima variabel ini dianggap berkontribusi signifikan terhadap pelaksanaan IMD, sesuai dengan hasil analisis bivariat. Namun, hanya variabel dukungan keluarga, pendidikan, dan tindakan bidan yang berpengaruh terhadap pelaksanaan IMD. Disadari bahwa ibu yang berpengetahuan cukup berpeluang besar untuk melakukan suatu pekerjaan, tetapi hal tersebut belum menjamin ibu mengambil keputusan. Salah satu penyebabnya adalah pengaruh situasi dan kondisi ibu yang masih kelelahan dalam menjalani proses persalinan sehingga proses IMD tidak dilaksanakan. Demikian juga dengan sikap, diantaranya pada saat proses persalinan ibu tidak didampingi keluarga, sehingga motivasi dari ibu itu sendiri kurang, apalagi tidak dibarengi dengan pengetahuan yang cukup tentang manfaat IMD. 


\section{Faktor faktor yang berhubungan tentang pelaksanaan}

IMD

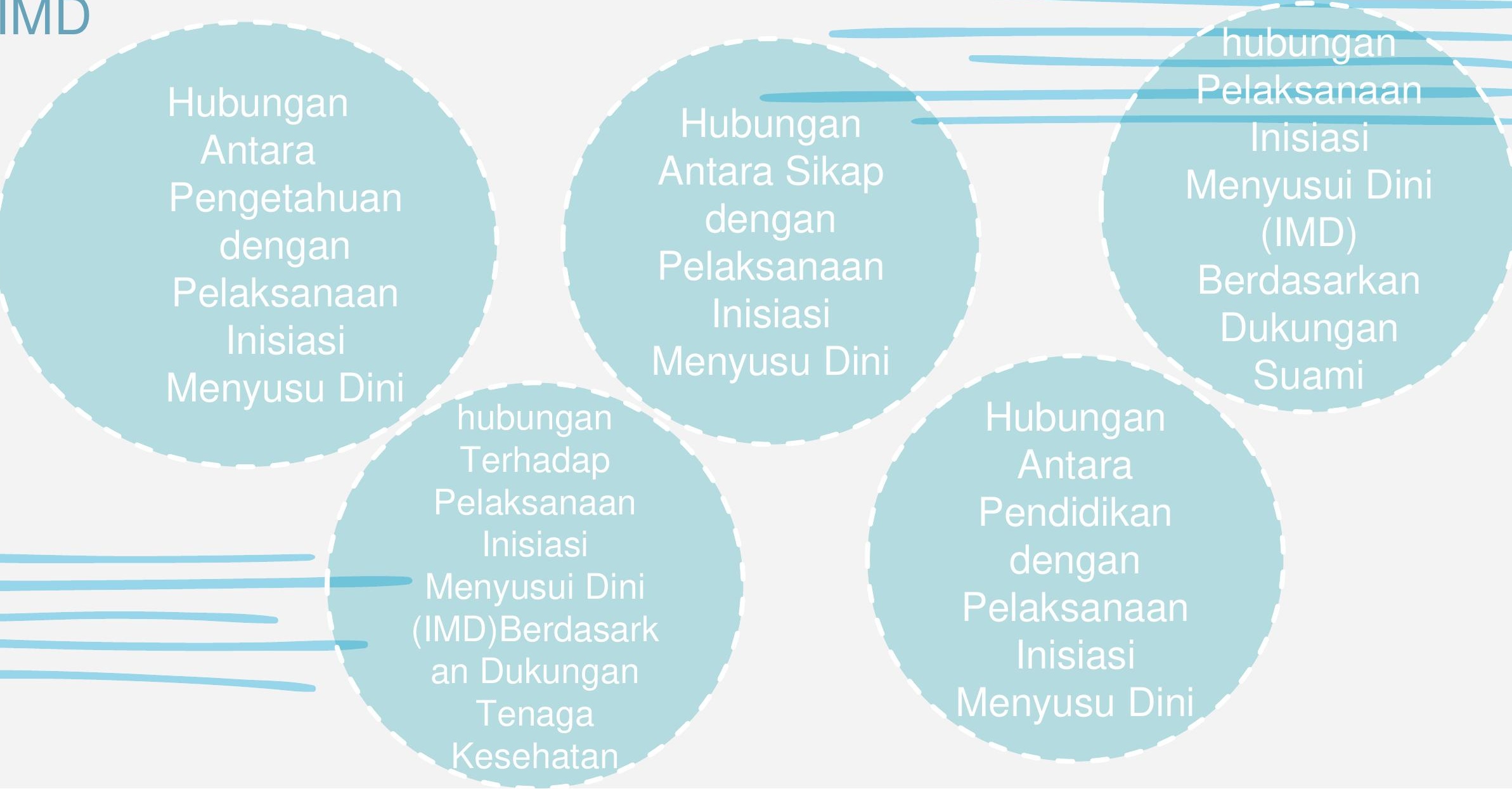




\section{PENGARUH IMD TERHADAP SUHU KEHILANGAN}

\section{PANAS BAYI BARU LAHIR}

Karakteristik fisik bayi baru lahir dan faktor lingkungan area persalinan berpengaruh kepada penurunan suhu bayi baru lahir, dan penurunan suhu tubuh yang cepat dapat terjadi jika tidak se gera dilakukan asuhan pencegahan kehilangan panas pada bayi baru lahir yaitu sekitar 0,1-0,30 C per menit. Berat badan dan luas permukaan tubuh meme-ngaruhi total kehilangan panas kering pada bayi baru lahir, dimana total kehilangan panas kering lebih tinggi pada bayi dengan berat badan lebih rendah dan luas permukaan tubuh yang rendah, dibandingkan dengan bayi baru lahir dengan berat badan lahir dan luas permukaan tubuh yang lebih besar. 


\section{Faktor yang mempengaruhi pemberian}

asi ekslusif

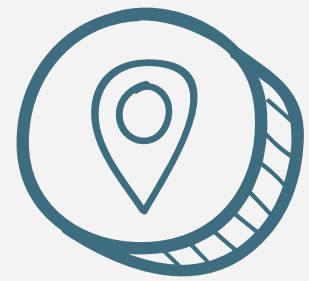

Faktor pemudah

- Pendidikan

- Pengetahuan

- nilai-nilai adat

- budaya

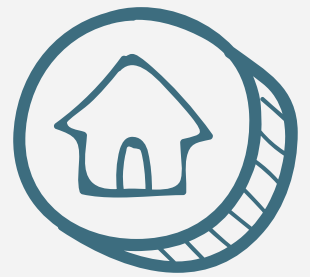

Faktor pendukung

- pendapatan keluarga

- ketersediaan waktu

- kesehatan ibu

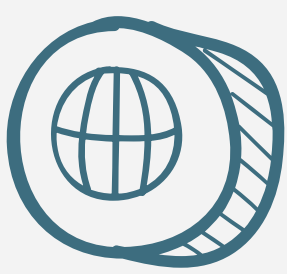

Faktor pendoron

- dưkungan keluarga

- Dukungan petugas kesehatan 
Hubungan pola makan dengan Asi Eksklusif dengan kejadian stunting

Menurut Riset Kesehatan Dasar (Riskesdas) tahun 2018, prevalensi underweight, stunting, wasting berturut-turut adalah 17,7 persen; 30,8 persen; dan 10,2 persen. Indonesia merupakan salah satu negara dengan prevalensi stunting cukup tinggi dibandingkan negara-negara berpendapatan menengah lainnya. Riskesdas tahun 2018 melaporkan prevalensi stunting dari tahun 2013 ke tahun 2018 mengalami penurunan sebesar 6,4 persen (Kemenkes, 2018).

Hasil penelitian menunjukkan bahwa tidak ada hubungan antara riwayat Asi Ekslusif dengan kejadian stunting pada balita dimana uji chi square memperlihatkan nilai $p$ value $=0,965 \leq \alpha \quad 0,05$. Sebanyak $89(30,4 \%)$ anak balita yang tidak mendapatka asi ekslusif dan 17 (25,3\%) anak balita yang mendapatkan asi ekslusif. 


\section{Bahaya Tidak Mendapatkan ASI}

\section{Ekslusif}

口ASI mengandung semua zat yang dibutuhkan oleh bayi selama enam bulan pertama kehidupannya, termasuk lemak, karbohidrat, protein, vitamin, mineral, dan air. Makronutrien utama dalam ASI adalah laktosa dan oligosakarida. ASI mudah dicerna dan efisien di gunakan. ASI juga mengandung faktor bioaktif yang membantu meningkatkan sistem kekebalan tubuh bayi yang belum matang, melindungi dari infeksi, dan faktor-faktor lain yang membantu pencernaan dan penyerapan nutrisi.

DUNICEF menyatakan bahwa 30.000 kematian anak di bawah lima tahun di Indonesia dan 10 juta kematian balita di seluruh dunia setiap tahun dapat dicegah dengan pemberian ASI saja selama 6 bulan sejak bayi pertama kali lahir, tanpa memberikan makanan dan minuman tambahan kepada bayi (Prasetyono, 2009). 


\section{Kandungan Gizi ASI Pada Berbagai Tempat}

Penyimpanan Dan Lama Penyimpanan

\begin{tabular}{c|c} 
No & Tempat \\
penyimpanan
\end{tabular}

1. Ruangan

2.

3. Freezer

4.

5. Freezer

\section{Lama penyimpanan}

\author{
Rerata kandungan \\ protein $n(\%)$
}

$0,7940 \pm 0.0194$

$0,7803 \pm 0.0252$

$0,7985 \pm 0.0131$

$0,8438 \pm 0.0509$

$0,8029 \pm 0.0320$

\section{Rerata kandungan \\ lemak k (\%)}

$2,1 \pm 0.089$

$2,4 \pm 0.421$

$2,3 \pm 0.697$

$1,5 \pm 0.392$

$2,7 \pm 0.670$

\section{Rerata kandungan} karbohidrat at (\%)

$9,23 \pm 0.057$

$9,17 \pm 0.057$

$9,13 \pm 0.057$

$9,00 \pm 0.057$

$9,03 \pm 0.057$ 
- Kandungan protein dalam sampel ASI berkisar antara 0,7940-0,8439\% atau setara dengan $8-8,5$ gram. Nilai ini hampir tidak berbeda dengan nilai rata-rata perkiraan konsentrasi zat gizi dalamASI, yaitu 9 g / liter ASI (Raaij, 2016). Kandungan protein cenderung meningkat dengan bertambahnya waktu penyimpanan. Situasi ini dapat dikaitkan dengan keadaan kehilangan air selama proses pembekuan dan pencairan kembali (Chang, et.al 2012). Proses pencairan kembali pada ASIP dapat menyebabkan terjadinya penggumpalan molekul protein sehingga menghasilkan nilai protein yang berbeda (Abranches, et.al, 2014)

DKandungan lemak dalam sampel ASI berkisar antara 1,5-2,7\% atau setara dengan 16-28 gram. Berbeda dengan nilai rata-rata perkiraan konsentrasi zat gizi dalam ASI, yaitu $37-40 \mathrm{~g} /$ liter ASI (Raaij, 2016). Kandungan lemak cenderung meningkat dengan bertambahnya waktu penyimpanan. Kandungan lemak ASI seolah-olah mengalami peningkatan kandungan lemak dikarenakan adanya aktifitas lipolisis. Aktifitas lipolisis terjadi lebih cepat pada suhu $25{ }^{\circ} \mathrm{C}$ atau suhu ruang dibanding pada suhu $15{ }^{\circ} \mathrm{C}$ atau lebih rendah (Hamosh, et.al, 1996). Perlakuan ke-1 dan ke-2 ASIP masih diletakkan pada suhu ruang, sedangkan pada perlakuan ke-3 sampai ke-5 ASI disimpan langsung di dalam freezer, sehingga proses lipolisis dihentikan.

- Kandungan karbohidrat dalam sampel ASI berkisar antara $9-9,23 \%$ atau setara dengan 90 - 92 gram. Berbeda dengan nilai rata-rata perkiraan konsentrasi zat gizi dalam ASI, yaitu $67 \mathrm{~g} /$ liter ASI (Raaij, 2016). Kandungan karbohidrat menurun dengan bertambahnya waktu penyimpanan. Lama penyimpanan ASIP mempengaruhi pertumbuhan bakteri. Bakteri dapat memecah karbohidrat dalam susu, yang berarti kandungan karbohidratnya rendah (Hamosh, et.al 1996). 


\section{DAFTAR PUSTAKA}

Simbung, R., \& Ohorella, F. (2021). Pentingnya Iniasiasi Menyusu Dini (IMD) Pada Bayi Baru Lahir. MEGA PENA: Jurnal Pengabdian Kepada Masyarakat, 1(1), 21-25.

Debataraja, F., Siregar, N. S. N., \& Batubara, W. M. (2021). FAKTOR-FAKTOR YANG BERHUBUNGAN DENGAN PELAKSANAAN INISIASI MENYUSUI DINI (IMD) DI PUSKESMAS BUTAR KECAMATAN PAGARAN KABUPATEN TAPANULI UTARA TAHUN 2020. Jurnal IImiah Kebidanan Imelda, 7(1), 12-18.

Irawan, J. (2018). Hubungan Inisiasi Menyusu Dini (IMD) dan Pemberian Air Susu Ibu (ASI) Eksklusif di RSUD Wangaya Kota Denpasar. Jurnal Skala Husada: The Journal of Health, 15(1).

Annisa, N., Sumiaty, S \& Tondong H. I. (2019) Hubungan inisiasi menyusu dini dan ASI Eksklusif dengan staunting pada Baduta Usia 7-24 bulan. Jurnal Bidan cerdas , $1(3), 137-143$ 


\section{DAFTAR PUSTAKA}

Maesarah, M., Adam, D., Hatta, H., Djafar, L., \& Ka'aba, I. (2021). Hubungan Pola Makan dan Riwayat ASI Ekslusif Dengan Kejadian Stunting Pada Balita di Kabupaten Gorontalo. AI GIZZAI: PUBLIC HEALTH NUTRITION JOURNAL, 1(1), 50-58.

Hutagaol, Hotma Sauhur, Eryati Darwin, and Eny Yantri. "Pengaruh Inisiasi menyusu dini (IMD) terhadap suhu dan kehilangan panas pada bayi baru lahir." Jurnal Kesehatan Andalas 3.3 (2014).

Raj, J. F., Fara, Y. D., Mayasari, A. T., \& Abdullah, A. (2020). Faktor yang mempengaruhi pemberian ASI eksklusif. Wellness And Healthy Magazine, 2(2), 283-291."

Handayani, S., Soekmawaty, D., Ariendha, R., \& Pratiwi, Y. S. (2019). Lama Penyimpanan Air Susu Ibu ( ASI ) Memengaruhi Kandungan Zat Gizi Dalam ASI. 7, 24-28. 
Salamah, U., Prasetya, P. H., Tiga, D., Sekolah, K.,Ilmu, T., Prima, K., Kebidanan, A., \& Agung, P. (2019). FAKTOR-FAKTOR YANG MEMPENGARUHIIBU DALAM KEGAGALAN PEMBERIAN. 5(3), 199-204.

Handayani, S., Soekmawaty, D., Ariendha, R., \& Pratiwi, Y. S. (2019). Lama Penyimpanan Air Susu Ibu ( ASI ) Memengaruhi Kandungan Zat Gizi Dalam ASI. 7, 24-28.

Widiyanto, Subur. Hubungan pendidikan dan pengetahuan ibu tentang ASI eksklusif dengan sikap terhadap pemberian ASI eksklusif. Diss. UNIMUS, 2012.

Gizi, K., Air, A. S. I., Ibu, S., Berbagai, P., Arum, P., \& Widiyawati, A. (n.d.). DAN LAMA PENYIMPANAN BREAST MILK NUTRIENT CONTENT IN DIFFERENT STORAGE. 200-203. 